(C) Springer-Verlag 1992

\title{
Ectomycorrhizal syntheses with Picea abies and three fungal species: a case study on the use of an in vitro technique to identify naturally occurring ectomycorrhizae
}

\author{
I. Brunner, R. Amiet, M. Zollinger, S. Egli \\ Swiss Federal Institute for Forest, Snow and Landscape Research (WSL), CH-8903 Birmensdorf, Switzerland
}

\begin{abstract}
Ectomycorrhizal syntheses between Picea abies and the fungal associates Scleroderma citrinum, Boletus luridus, and Tricholoma vaccinum were carried out using Melin's Erlenmeyer flask technique. The symbioses of $S$. citrinum were characterized by a mantle composed of an outer prosenchymatous and an inner synenchymatous layer. The mantles of $B$. luridus and $T$. vaccinum were solely prosenchymatous. Rhizomorphs were produced in all treatments, but only in association with $S$. citrinum were they differentiated with additional, enlarged hyphae. All synthesized ectomycorrhizae were white or whitish to light orange and greyishorange. On large-scale root sampling in two differing Picea abies forests in Switzerland, nine out of a total of 22 morphological types of ectomycorrhizae were white or yellow in colour and were, therefore, comparable with the synthesized ectomycorrhizae. These nine natural types generally had distinct mantle features (irregular synenchyma, gelatinous matrix, cystides, thick-walled hyphae), but mostly lacked clamp connections. Synthesized ectomycorrhizae, on the other hand, lacked distinct mantle characteristics and always had clamp connections. Natural and synthesized white or yellow ectomycorrhizae did not coincide morphologically and thus identification of the fungal partners of natural symbioses by means of in vitro-synthesis with potential ectomycorrhizal fungi was not possible in the present study.
\end{abstract}

Key words: Ectomycorrhizal synthesis - Erlenmeyer flask technique - Picea abies - Large-scale root sampling - Morphological types

\section{Introduction}

Melin's Erlenmeyer flask technique (Melin 1922) is a useful tool to obtain in vitro syntheses of ectomycorrhizae for morphological and anatomical characterization.

Correspondence to: I. Brunner
Therefore, both well- and little-documented fungal isolates from Swiss Picea abies (L.) Karst. forests were used to describe the symbioses derived: Tricholoma vaccinum (Pers.: Fr.) Kummer and Hebeloma crustuliniforme (Bull. ex St. Amans) Quél. have frequently been reported in subalpine spruce forests in the canton of Graubünden (Favre 1960; Horak 1963, 1985), Boletus luridus Schff.: Fr. has been found only occasionally in association with spruce (Horak 1985) but also in conifer and hardwood forests (Breitenbach and Kränzlin 1991), and Scleroderma citrinum Pers. is a species of mixed conifer and hardwood forests (Breitenbach and Kränzlin 1986).

The same in vitro technique is also considered to be a useful tool for identifying fungal partners of naturally occurring ectomycorrhizae through morphological comparison (Zak 1973). Recent studies using seedlings of $P i$ cea abies and Larix leptolepis (Sieb. et Zucc.) Gordon and the fungal partners Amanita muscaria (L.: Fr.) Hooker, $H$. crustuliniforme, and Suillus grevillei (Klotzsch) Sing. confirmed that natural and in vitro synthesized symbioses show no significant morphological and anatomical differences at least for these species (Kottke 1986; Brunner et al. 1991). This method appears, therefore, to be really suitable for fungall identification, but the question remains whether it is appropriate for routine identification of natural ectomycorrhizae obtained by large-scale root sampling.

Egli (1991) investigated the ectomycorrhizal types associated with Norway spruce (Picea abies) in a 3-year study at two different spruce stands in Switzerland. In total he observed 22 varying morphological types of ectomycorrhizae coloured white, grey, yellow, brown or black. Three types could be morphologically identified with the aid of Agerer's colour atlas of ectomycorrhizae (Agerer 1987a) as Cenococcum geophilum Fr., Piloderma croceum Erikss. and Hjortst., and Tuber puberulum Berk. and Br. Three further types were classified as Russula sp., Cortinarius sp., and 'pseudomycorrhizae'. The present study was an attempt to identify the fungal partners of Egli's investigation with the aid of syntheses cultured with the Erlenmeyer flask technique. The mor- 
phology of synthesized and naturally occurring ectomycorrhizae of $\boldsymbol{H}$. crustuliniforme - Picea abies has already been described (Brunner 1991; Brunner et al. 1991; Brunner and Scheidegger 1992).

\section{Materials and methods}

\section{Ectomycorrhizal syntheses}

Plant and fungal materials. Seeds of Picea abies originated from Dielsdorf (canton of Zürich, Switzerland) and were collected in 1977. For germination, the seeds were surface sterilized for $30 \mathrm{~min}$ in $30 \% \mathrm{H}_{2} \mathrm{O}_{2}$ and placed on water-agar plates. After 2 to 3 weeks, the seedlings could be used for synthesis experiments. Mycelia were isolated from fruit bodies collected in Switzerland between 1989 and 1990. Fruit bodies of T. vaccinum were collected in association with Picea abies in the canton of Freiburg, B. luridus was collected in association with Picea abies in the canton of Glarus, and $S$. citrinum was collected from fruit bodies in association with Castanea sativa Mill. in the arboretum of the Swiss Federal Institute for Forest, Snow and Landscape Research (WSL), Birmensdorf.

Synthesis experiments. Fungal materials were pregrown for a few weeks on a shaker in Erlenmeyer flasks containing modified Melin-Norkrans solution (MMN; Marx and Bryan 1975) including glucose $(10 \mathrm{~g} / 1)$ and malt $(3 \mathrm{~g} / \mathrm{l})$. The fungal mycelia were then homogenized with a blender and introduced into further Erlenmeyer flasks using an inversed pipette. The Erlenmeyer flasks $(500 \mathrm{ml})$ were filled with a vermiculite: peat moss mixture $(200 \mathrm{ml}: 30 \mathrm{ml})$ and $150 \mathrm{ml}$ MMN solution and autoclaved $(\mathrm{pH} 5.5)$. The fungal inocula were allowed to grow for about 1 month prior to seedling introduction. The synthesis experiments were carried out in a growth chamber with a 16-h day period (PAR: $100 \mu \mathrm{mol} \cdot \mathrm{m}^{-2} \cdot \mathrm{s}^{-1}$ ) at $20^{\circ} \mathrm{C}$ and $70 \%$ humidity. The durations of the syntheses were 123 days ( $T$. vaccinum) and 137 days (S. citrin$u m$, B. (uridus). Ectomycorrhizal rootlets were fixed in $2.5 \%$ glutaraldehyde and stored at $4^{\circ} \mathrm{C}$ in the dark.

\section{Analyses of synthesized ectomycorrhizae}

Ectomycorrhizal plants were carefully washed out of the Erlenmeyer flasks with water, and the attached substratum was gently removed by washing and with the aid of fine forceps. The morphology of the ectomycorrhizae was studied under a Wild M8 dissecting microscope using cold lights. Colours were assigned according to Kornerup and Wanscher (1978). To study anatomical characteristics, ectomycorrhizal rootlets and rhizomorphs were dehydrated in alcohol, embedded in glycol-methacrylate, longitudinally sectioned $(1.5 \mu \mathrm{m})$, and stained with Giemsa for chitinoid material (Clark 1981). Drawings of ectomycorrhizae and rhizomorphs were made with the aid of a drawing tube attached to a Wild M20 microscope. Anatomical comparisons of the surface and the outer and inner layer of the mantle were made using the middle portions of tangential longitudinal sections. Rhizomorphs were sectioned longitudinally.

\section{Large-scale root sampling}

Naturally grown ectomycorrhizae were investigated over a 3-year period from 1986 to 1988 at two sites in Switzerland (Lägern, canton of Zürich and Davos, canton of Graubünden) with $P$. abies as the dominant tree species (Egli 1991). At each site, four mature trees in different states of health were chosen and four root sam- ples per tree were taken each month during the vegetation period to a depth of $15 \mathrm{~cm}$ with a soil-coring cylinder $6.4 \mathrm{~cm}$ in diameter. Ectomycorrhizal rootlets were gently washed out and their morphology studied under a Wild M8 dissecting microscope. To study anatomical characters, ectomycorrhizal rootlets were treated in the same way as the synthesized material.

\section{Results}

\section{S. citrinum ectomycorrhizae}

Fungal mycelia colonized the substrate within the Erlenmeyer flasks homogeneously and ectomycorrhizal rootlets developed abundantly throughout the substratum.

Morphological characteristics. Ectomycorrhizae irregularly monopodial to almost monopodial pinnate, up to $5 \mathrm{~mm}$ long and up to $0.5 \mathrm{~mm}$ thick, straight to slightly coiled, clavate to cylindrical, with rounded apices. Ectomycorrhizal rootlets and apices white with brown patches. Surface smooth with short and irregularly emanating hyphae. Rhizomorphs abundant, mostly along main axes, also forming dense and flat interconnected filaments, pale orange to orange-white.

Anatomical characteristics. Outer surface of mantle a loose prosenchymatous net, hyphae often branched, 2$5 \mu \mathrm{m}$ broad, clamp connections rarely present (Fig. 1a). Middle layer of mantle irregularly prosenchymatous with dense synenchymatous patches, prosenchymatous elements $3-5 \mu \mathrm{m}$ broad, synenchymatous elements 2.5 $7 \mu \mathrm{m}$ broad, irregularly formed and of various sizes, clamp connections not observed (Fig. 1b). Inner surface of mantle densely synenchymatous with few prosenchymatous elements, synenchymatous elements $2.5-5 \mu \mathrm{m}$ broad, clamp connections not observed (Fig. 1c). Mantle mostly thin and up to $35 \mu \mathrm{m}$ thick, no layering recognizable (Fig. 1f). Hartig net composed of distinct fingerlike palmettes, reaching up to the endodermis, mostly one hyphal cell row between epidermal and cortical cells, hyphae and lobes of palmettes $1.5-6 \mu \mathrm{m}$ broad. Rhizomorphs up to $40 \mu \mathrm{m}$ in diameter, roundish, composed mainly of large elements with few regular hyphae, large elements $10-15 \mu \mathrm{m}$ in diameter, hyaline, regular hyphae $2.5-4 \mu \mathrm{m}$ in diameter, hyaline, clamp connections not observed (Fig. 1d). Emanating hyphae very variable, straight to strongly coiled, branched, 3-8 $\mu \mathrm{m}$ broad, hyaline, clamp connections not observed (Fig. 1e).

\section{B. luridus ectomycorrhizae}

Fungal mycelia colonized the substrate within the Erlenmeyer flasks slowly and ectomycorrhizal rootlets developed only sparsely and patchily in the substratum.

Morphological characteristics. Ectomycorrhizae irregularly monopodial, up to $8 \mathrm{~mm}$ long and up to $0.5 \mathrm{~mm}$ thick, straight to slightly coiled, cylindrical, with 

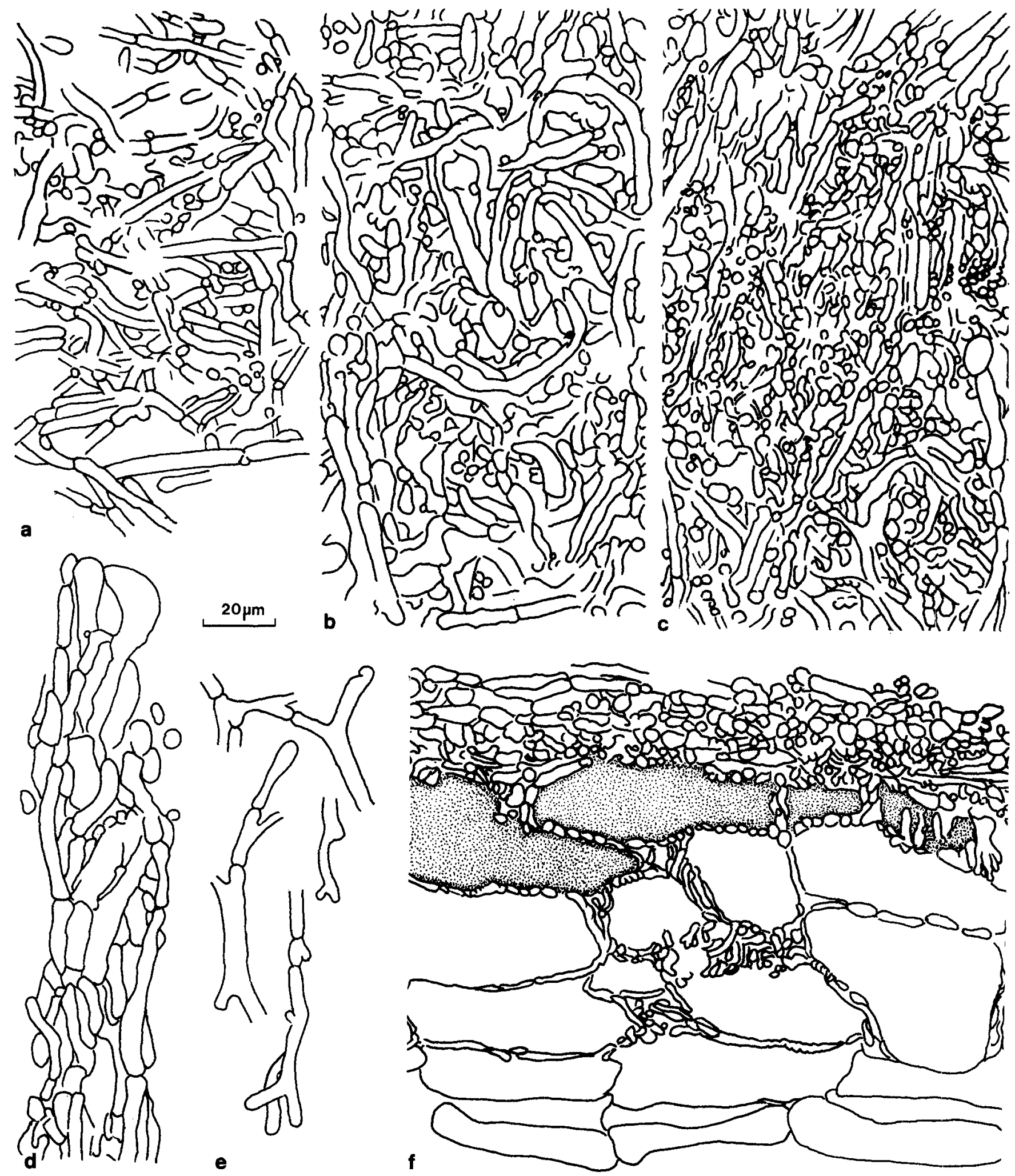

Fig. 1a-f. Line drawings of synthesized Scleroderma citrinum Picea abies ectomycorrhizae. a Tangential section through the prosenchymatous surface of the mantle. b Tangential section through the outer prosenchymatous layer of the mantle. $c$ Tangen-

tial section through the synenchymatous inner layer of the mantle. d Longitudinal section through a differentiated rhizomorph. e Emanating hyphae of the mantle surface. $f$ Longitudinal central section through the middle portion of a rootlet 
rounded apices. Ectomycorrhizal rootlets and apices whitish to light orange. Surface smooth with a loose mantle and short and irregularly emanating hyphae. Rhizomorphs abundant, and also forming flattened and woolly mycelial mats, light orange.

Anatomical characteristics. Outer surface of mantle a loose prosenchymatous net, hyphae often branched, 2.5-4 $\mu \mathrm{m}$ broad, clamp connections seldom observed (Fig. 2a). Middle layer of mantle dense prosenchymatous, hyphae variable, $2-6.5 \mu \mathrm{m}$ broad, clamp connections rarely observed (Fig. 2b). Inner surface of mantle densely prosenchymatous with few synenchymatous elements, prosenchymatous elements $2-6.5 \mu \mathrm{m}$ broad, synenchymatous elements $2-3 \mu \mathrm{m}$ broad, clamp connections seldom observed (Fig. 2c). Mantle 30-50 $\mu \mathrm{m}$ thick, no layering recognizable (Fig. 2d). Hartig net composed of distinct finger-like palmettes, reaching up to the endodermis, mostly one hyphal cell row between epidermal and cortical cells, hyphae and lobes of palmettes $1.5-3.5 \mu \mathrm{m}$ broad. Rhizomorphs up to $50 \mu \mathrm{m}$ in diameter, roundish, composed of undifferentiated regular hyphae, hyaline, 2.5-3.5 $\mu \mathrm{m}$ in diameter, clamp connections abundant (Fig. 2f). Emanating hyphae straight to curved, single or branched, $2.5-4.5 \mu \mathrm{m}$ broad, hyaline, hyphal walls thickened, clamp connections abundant (Fig. 2e).

\section{T. vaccinum ectomycorrhizae}

Fungal mycelia colonized the substrate within the Erlenmeyer flasks homogeneously and ectomycorrhizal rootlets developed abundantly throughout the substratum.

Morphological characteristics. Ectomycorrhizae irregularly monopodial to almost monopodial pinnate, up to $6 \mathrm{~mm}$ long and up to $0.5 \mathrm{~mm}$ thick, straight to slightly coiled, cylindrical to clavate, with rounded apices. Ectomycorrhizal rootlets and apices whitish- to greyishorange. Surface smooth with short and irregularly emanating hyphae. Rhizomorphs abundant, also forming dense smooth mycelial mats, whitish- to greyishorange.

Anatomical characteristics. Outer surface of mantle loosely prosenchymatous, hyphae often branched, 2.5$6.5 \mu \mathrm{m}$ broad, clamp connections not observed (Fig. $3 a)$. Middle and inner layer of mantle densely prosenchymatous with synenchymatous elements, hyphal elements $2-4.5 \mu \mathrm{m}$ broad, clamp connections not observed (Fig. 3b). Mantle up to $60 \mu \mathrm{m}$ thick, no layering recognizable (Fig. 3e). Hartig net composed of distinct fingerlike palmettes reaching up to the endodermis, mostly one hyphal cell row between epidermal and cortical cells, hyphae and lobes of palmettes $1.5-3.5 \mu \mathrm{m}$ broad. Rhizomorphs up to $65 \mu \mathrm{m}$ in diameter, roundish, composed of undifferentiated or slightly modified regular hyphae, hyaline, 3.5-6.5 $\mu \mathrm{m}$ in diameter, clamp connections seldom observed in the outer rhizomorphal region (Fig. 3c). Emanating hyphae straight, single or branched, 3-4.5 $\mu \mathrm{m}$ broad, hyaline, clamp connections often observed (Fig. 3d).

$T$. vaccinum had also been used successfully as a fungal partner to form ectomycorrhizae with the semi-aseptic growth pouch technique (C. Scheidegger and I. Brunner, unpublished work). Derived ectomycorrhizae were morphologically identical to those obtained by the Erlenmeyer flask technique and, therefore, are not considered in the present study. Naturally occurring ectomycorrhizae from soil samples underneath fruiting bodies of $T$. vaccinum within a nearly pure Picea abies forest in the canton of Freiburg were morphologically and anatomically similar to those synthesized. The only differences were the presence of a few clamp connections in the outer mantle surface and differentiated rhizomorphs composed of regular and enlarged hyphae in the natural ectomycorrhiza.

\section{Ectomycorrhizae from large-scale root sampling}

In total, 22 different ectomycorrhizal types were recorded. Of these, 19 types were observed at Lägern, 16 types at Davos, and 13 types were common to both stands. These types were distinguished by several distinct colours including white, yellow, grey, pinkish-grey, greenish-grey, brown, reddish-brown, purplish-brown, and black. Eleven of the 22 types were not identified and were either whitish or yellowish and, therefore, comparable with the synthesized ectomycorrhizae. Most of these 11 types had distinct characteristics: types 9, 101,102 , and 107 had irregular synenchyma in the mantles, types $1,2,7,8,9$, and 107 had a gelatinous matrix in the mantles, types 2 and 9 had thick-walled hyphae, and type 106 had superficial cystides (Table 1). The remaining two types $(108,109)$ lacked clamp connections.

The synthesized ectomycorrhizae lacked distinct mantle characteristics, e.g. irregular synenchyma, gelatinous matrix, cystides, or thick-walled hyphae (Table 1). On the other hand, clamp connections were observed in all synthesized material.

\section{Discussion}

S. citrinum (syn. S. aurantium Vaill. ex. Pers.) is known to form ectomycorrhizae in vitro with a wide range of host species. Modess (1941) and Fries (1942) synthesized this species with Picea abies and Pinus spp. over 50 years ago. Richter and Bruhn $(1986,1990)$ synthesized it with Pinus and Larix, Godbout and Fortin $(1983,1985)$ with Alnus and Populus, and Voiry (1981) with Quercus; all of them reported that the symbioses had a white mantle, including whitish mycelial strands. Voiry (1981) differentiated an outer prosenchymatous and an inner synenchymatous mantle similar to that described here. The white to whitish colour of the ectomycorrhiza and the rhizomorphs may be typical of the genus Scleroder$m a$ since Molina and Trappe (1982) and Rose et al. (1981) noted this colour when they synthesized $S$. hypo- 

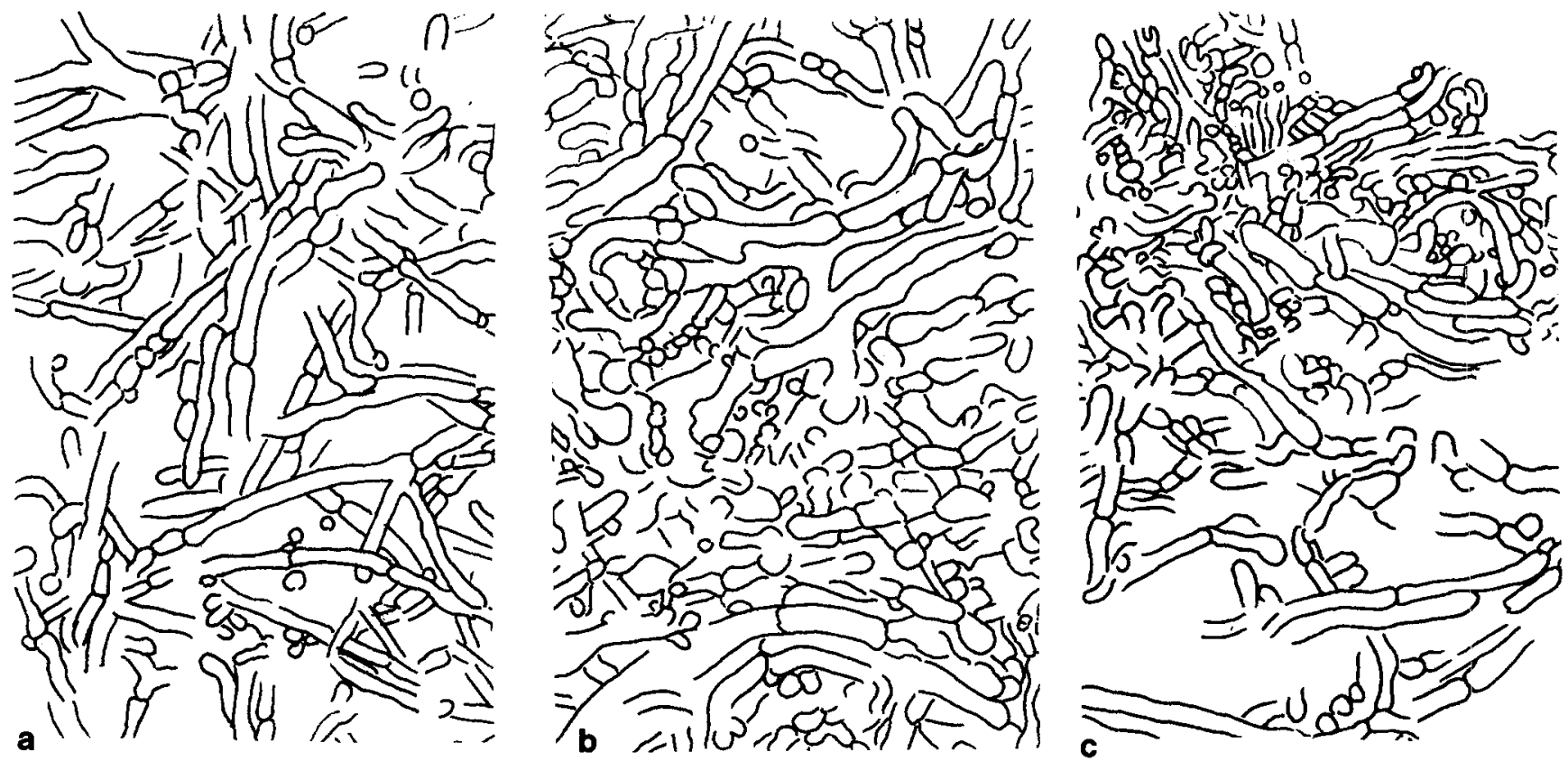

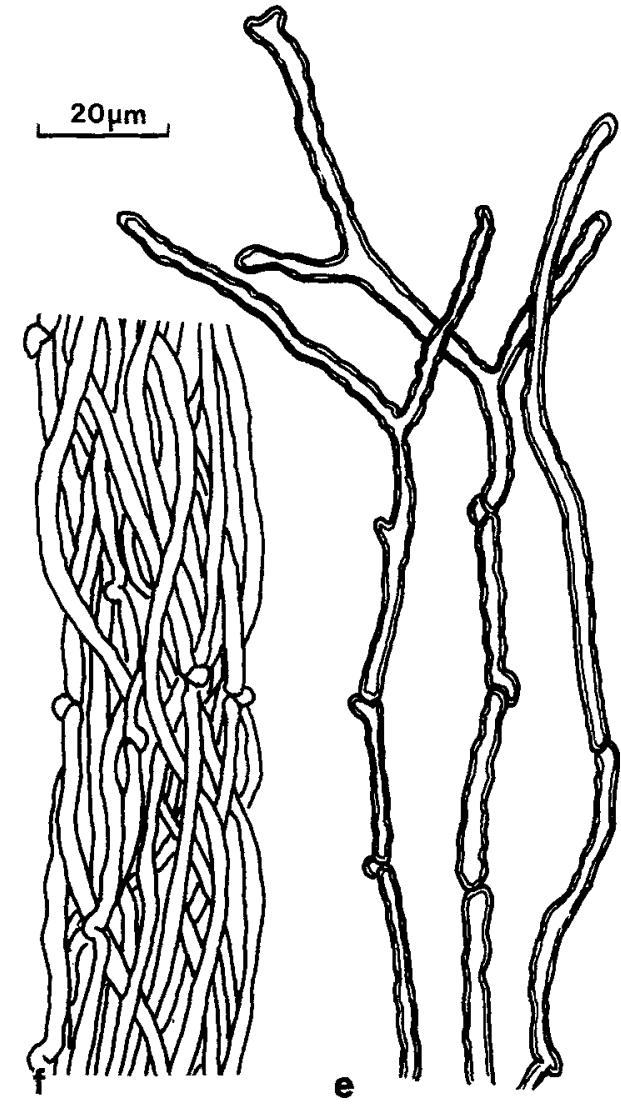

Fig. 2a-f. Line drawings of synthesized Boletus luridus - Picea abies ectomycorrhizae. a Tangential section through the prosenchymatous surface of the mantle. $b$ Tangential section through the prosenchymatous outer layer of the mantle. $c$ Tangential section

gaeum Zeller with various conifer species from the $\mathrm{Pa}$ cific Northwest and $S$. geaster Fr. with a Eucalyptus species.

$B$. luridus is an almost unknown species in the literature concerning in vitro syntheses. Fries (1942) was suc- through the prosenchymatous inner layer of the mantle. d Longitudinal central section through the middle portion of a rootlet. $\mathrm{e}$ Thick-walled emanating hyphae of the mantle surface. $f$ Longitudinal section through an undifferentiated rhizomorph cessful in synthesizing $B$. luridus with Pinus silvestris L. but not with Picea abies. Modess (1941) failed to synthesize this species with both Picea abies and Pinus silvestris. However, Trappe (1962) reported the species as an associate of a broad host range (e.g. Pinus, Carpinus, 

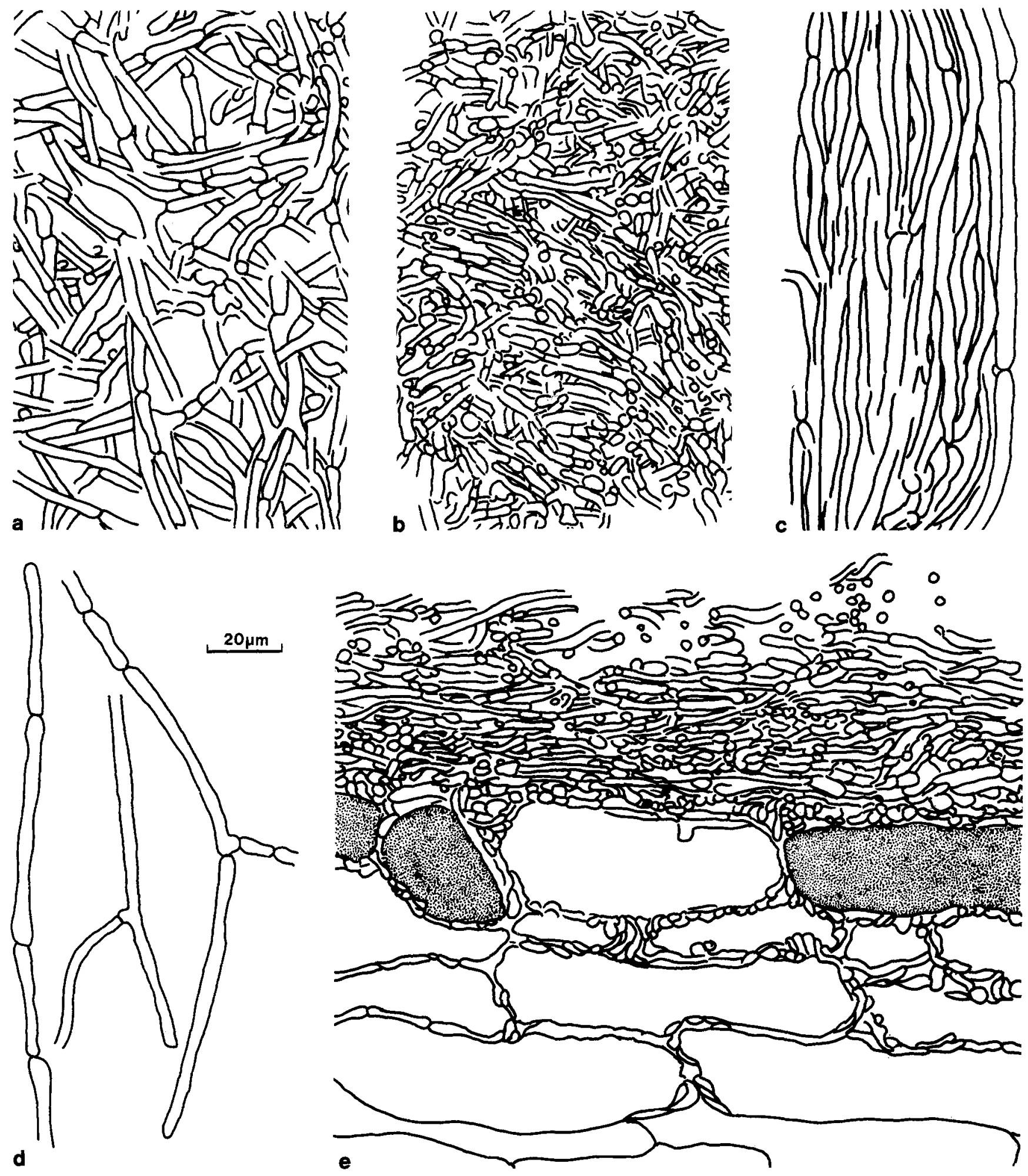

Fig. 3a-e. Line drawings of synthesized Tricholoma vaccinum Picea abies ectomycorrhizae. a Tangential section through the prosenchymatous surface of the mantle. b Tangential section through the prosenchymatous outer and inner layer of the mantle.

c Longitudinal section through an undifferentiated rhizomorph. d Emanating hyphae of the mantle surface. e Longitudinal central section through the middle portion of a rootlet

Castanea, Fagus, Quercus). In association with Picea, Trappe (1962) reported Boletus edulis as the sole Boletus associate, the symbiosis of which was described by Gronbach (1988) and Agerer (1987a) as a whitish, smooth ectomycorrhiza with abundant rhizomorphs.
There is not enough information in the literature to decide whether ectomycorrhizae in the genus Boletus are generally similar or diverse. One overview of the current knowledge of Boletus ectomycorrhizae by Gronbach (1988) tends towards divergency within that genus. 
Table 1. Characteristics of unidentified natural whitish and yellowish ectomycorrhizal types and synthesized ectomycorrhizae of Picea abies. Mantle structures according to Ingleby et al. (1990):
FP/NP, felt/net prosenchyma; NS/IS/RS, net/irregular/regular synenchyma. MS, Mantle surface; OM, outer mantle; IM, inner mantle

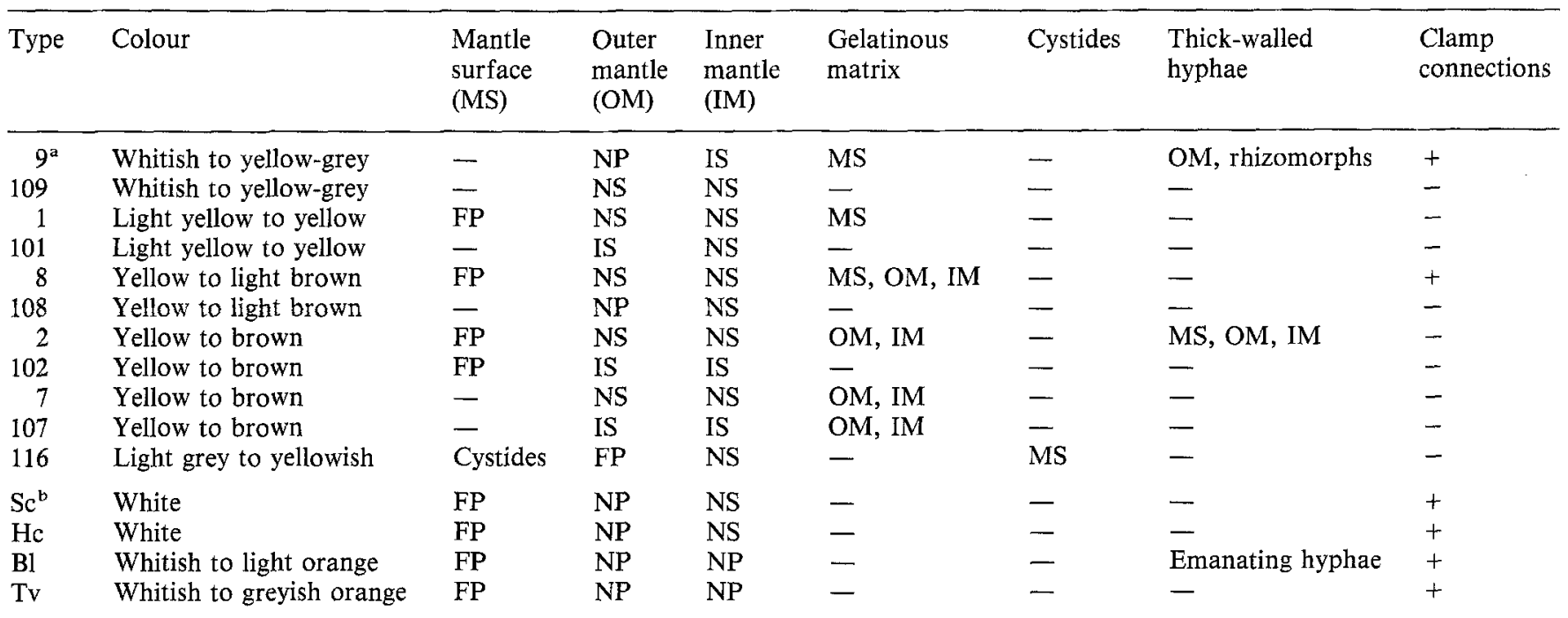

${ }^{a}$ Natural ectomycorrhizal types from Davos (types 1-9) and Lägern (types 101-116)

T. vaccinum is known to form ectomycorrhizae mainly with Picea and Pinus (Trappe 1962). Modess (1941) successfully synthesized this species with Pinus sylvestris, but failed with Picea abies and with Pinus montana Miller. The ectomycorrhiza in association with Picea abies has been extensively described from natural material by Agerer (1987a, 1987b) and is identical to our own investigated natural material. Only slight differences occur between natural and synthesized ectomycorrhizae (clamp connections in the outer mantle surface, differentiation of rhizomorphs). Both characters may be dependent on the age of the ectomycorrhiza and may, therefore, be considered as non-stable features which develop gradually (compare also Brunner et al. 1991). Ectomycorrhizae in the genus Tricholoma produce strongly differing ectomycorrhizae (Agerer 1987b) and rhizomorphal differentiation has been used to key out species (Uhl 1988). Obviously, the colour can differ within that genus from white to whitish- or even hazelbrown (Agerer 1987b).

The large-scale root sampling at two different sites gave a broad variety, over 20 types, of ectomycorrhizal rootlets. On the basis of morphological description, three types (Cenococcum geophilum, Tuber puberulum, Piloderma croceum) could be identified with the help of Agerer's ectomycorrhizal atlas (Agerer 1987a). No types were identified with the in vitro synthesis technique due to disagreements in morphology between natural and synthesized symbioses. Thus, the attempt to identify fungal partners of natural morphological types by means of in vitro syntheses with potential ectomycorrhizal fungi failed. All synthesized types in the present investigation mainly lacked distinct mantle characteristics (e.g. irregular synenchyma, gelatinous matrix, cystides, thick-walled hyphae). On the other hand, clamp connec-
${ }^{b}$ Synthesized ectomycorrhizae. Sc, Scleroderma citrinum; Hc, Hebeloma crustuliniforme; Bl, Boletus luridus; Tv, Tricholoma vaccinum

tions were always present in synthesized but seldom in natural material. The synthesized symbioses are morphologically very similar to each other, although the fungal species belong taxonomically to rather diverse groups: Sclerodermatales, Boletales, and Agaricales. The following hypotheses can be offered for the failure of the method: first, the ectomycorrhizal species used do not form ectomycorrhizae on these stands due to the lack of an inoculum; second, the strains are incompatible with Picea abies on these stands for unknown reasons; third, the sampling method does not record all occurring types; fourth, the fungal species used in the syntheses form other types than those in nature. With regard to the last-mentioned point, there is evidence that natural and in vitro synthesized ectomycorrhizae are more or less identical (Kottke 1986; Brunner et al. 1991). For the moment, the remaining hypotheses can be neither neglected or excluded. In addition, one morphological type could be just one or more than one fungal species, and the identification of types by in vitro syntheses may furnish only one possible identification and never be absolute. Horak (1985) estimated 132 ectomycorrhizal species in an equivalent subalpine Norway spruce stand close to the Swiss National Park (canton of Graubünden). Compared to 16 morphological types at $\mathrm{Da}$ vos, it is highly possible that several species can form one particular morphological type.

From these results, it may be concluded that the possibility of identifying natural ectomycorrhizae with the aid of in vitro syntheses is low. Definite identification would be easier if the ectomycorrhizal fungal flora of the sites obtained by fruit body recording were known and if syntheses were made with these records. However, any morphological similarity between natural and synthesized symbioses would still lead to uncertainty as 
to whether a particular ectomycorrhiza is formed by the same fungal species. Methods other than morphological analysis may be much more appropriate and in fact have already been successfully applied. Such methods include the use of isoenzyme analysis (Dahlberg and Wallander 1990; Sen 1990) or the use of restriction fragment length polymorphisms or sequence variations of variable and highly conserved regions of the DNA (Gardes et al. 1991). The latter method may be that of the future, since the application of the polymerase chain reaction makes it unnecessary to cultivate the mycobiont, DNA extractions can readily be made from freshly excised ectomycorrhizal rootlets and amplified, and the results are highly specific.

Acknowledgements. We thank Mrs. B. Schneider for sectioning and staining the ectomycorrhizae, Mr. F. Ayer for collecting natural T. vaccinum ectomycorrhizae, and Mrs. M. J. Sieber for correcting the English text.

\section{References}

Agerer R (1987a) Colour atlas of ectomycorrhizae. Einhorn, Schwäbisch Gmünd

Agerer R (1987b) Studies on ectomycorrhizae. IX. Mycorrhizae formed by Tricholoma sulfureum and $T$. vaccinum on spruce. Mycotaxon 28:327-360

Breitenbach J, Kränzlin F (1986) Pilze der Schweiz. II. Aphyllophorales. Mykologia, Luzern

Breitenbach J, Kränzlin F (1991) Pilze der Schweiz. III. Röhrlinge und Blätterpilze. Mykologia, Luzern

Brunner I (1991) Comparative studies on ectomycorrhizae synthesized with various in vitro techniques using Picea abies and two Hebeloma species. Trees 5:90-94

Brunner I, Scheidegger C (1992) Ontogeny of synthesized Picea abies (L.) Karst. Hebeloma crustuliniforme (Bull. ex. St. Amans) Quél. ectomycorrhizas. New Phytol 120:359-369

Brunner I, Amiet R, Schneider B (1991) Characterization of naturally grown and in vitro synthesized ectomycorrhizae of Hebeloma crustuliniforme and Picea abies. Mycol Res 95:14071413

Clark G (1981) Staining procedures. Williams \& Wilkins, Baltimore

Dahlberg A, Wallander H (1990) Ectomycorrhizal communities in coniferous forest soil reflected by isoenzymatic analyses of mycorrhizae and sporocarps (abstract). In: Allen MF, Williams SE (eds) Eighth North American Conference on Mycorrhizae. University of Wyoming, Jackson, WY, p 65

Egli S (1991) Morphologische Untersuchungen der Mykorrhizaverhältnisse an Fichten auf den Beobachtungsflächen Lägern und Davos. In: Stark M (ed) Lufthaushalt, Luftverschmutzung und Waldschäden in der Schweiz. V. Luftschadstoffe und Wald. Verlag der Fachvereine, Zürich, pp 187-193

Favre J (1960) Catalogue descriptif des champignons supérieurs de la zone subalpine du parc national suisse. Ergeb Wiss Untersuch Schweiz Nationalparkes 6:323-610

Fries N (1942) Einspormycelien einiger Basidiomyceten als Mykorrhizabildner von Kiefer und Fichte. Sven Bot Tidskr 36:151-156

Gardes M, White TJ, Fortin JA, Bruns TD, Taylor JW (1991) Identification of indigenous and introduced symbiotic fungi in ectomycorrhizae by amplification of nuclear and mitochondrial DNA. Can J Bot 69:180-190
Godbout C, Fortin JA (1983) Morphological features of synthesized ectomycorrhizae of Alnus crispa and A. rugosa. New Phytol $94: 249-262$

Godbout C, Fortin JA (1985) Synthesized ectomycorrhizae of aspen: fungal genus level of structural characterization. Can J Bot $63: 252-262$

Gronbach E (1988) Charakterisierung und Identifizierung von Ektomykorrhizen in einem Fichtenbestand mit Untersuchungen zur Merkmalsvariabilität in sauer beregneten Flächen. Bibl Mycol 125:1-216

Horak E (1963) Pilzökologische Untersuchungen in der subalpinen Stufe (Piceetum subalpinum und Rhodoreto-Vaccinietum) der rätischen Alpen. Mitt Schweiz Anst Forstl Versuchswes $31: 1-112$

Horak E (1985) Die Pilzflora (Macromyceten) und ihre Ökologie in fünf Pflanzengesellschaften der montan-subalpinen Stufe des Unterengadins (Schweiz). Ergeb Wiss Untersuch Schweiz Nationalparkes 12:337-476

Ingleby K, Mason PA, Last FT, Fleming LV (1990) Identification of ectomycorrhizas. Her Majesty's Stationary Office, London

Kornerup A, Wanscher JH (1978) Methuen handbook of colour. Methuen, London

Kottke I (1986) Charakterisierung und Identifizierung von Mykorrhizen. In: Einsele G (ed) Das landschaftsökologische Forschungsprojekt Naturpark Schönbuch (Forschungsbericht). Deutsche Forschungsgemeinschaft, Weinheim, pp 463-485

Marx DH, Bryan WC (1975) Growth and ectomycorrhizal development of loblolly pine seedlings in fumigated soil infested with the fungal symbiont Pisolithus tinctorius. For Sci $21: 245$ 254

Melin E (1922) Untersuchungen über die Larix-Mykorrhiza. I. Synthese der Mykorrhiza in Reinkultur. Sven Bot Tidskr $16: 161-196$

Modess O (1941) Zur Kenntnis der Mykorrhizabildner von Kiefer und Fichte. Symb Bot Ups 5: 1-146

Molina R, Tappe JM (1982) Patterns of ectomycorrhizal host specificity and potential among Pacific northwest conifers and fungi. For Sci 28:423-458

Richter DL, Bruhn JN (1986) Pure culture synthesis of Pinus resinosa ectomycorrhizae with Scleroderma aurantium. Mycologia 78:139-142

Richter DL, Bruhn JN (1990) Scleroderma citrinum (Gastromycetes, Sclerodermatales) and Larix decidua form ectomycorrhiza in pure culture. Nova Hedwigia Z Kryptogamenkd 50:355360

Rose RW Jr, Van Dyke CG, Davey CB (1981) Scanning electron microscopy of three types of ectomycorrhizae formed on $E u c a$ lyptus nova-anglica in the southeastern United States. Can J Bot 59:683-688

Sen R (1990) Isozymic identification of individual ectomycorrhizas synthesized between Scots pine (Pinus sylvestris L.) and isolates of two species of Suillus. New Phytol 114:617-626

Trappe JM (1962) Fungus associates of ectotrophic mycorrhizae. Bot Rev $28: 538-606$

Uhl M (1988) Studies on ectomycorrhizae. XVI. Ectomycorrhizae formed by Tricholoma flavobrunneum and Betula pendula and Tricholoma auratum and Pinus silvestris. Mycotaxon 33:1-21

Voiry H (1981) Classification morphologique des ectomycorrhizes du chêne et du hêtre dans le nord-est de la France. Eur J For Pathol 11:284-299

Zak B (1973) Classification of ectomycorrhizae. In: Marks GC, Kozlowski TT (eds) Ectomycorrhizae. Academic Press, New York, pp 43-78 